Review Article

\title{
HPV infection as a risk factor of esophagus squamous cell carcinoma and it prognosis
}

\author{
A infecção do HPV como fator de risco para o carcinoma de células escamosas de \\ esôfago e seu prognóstico
}

\section{Ana Carolina Ferrari Nassar ${ }^{1}$, Débora de Oliveira Garcia ${ }^{1}$, Júlia Royd Costa Salvio ${ }^{1}$, Nathalie Gabrielle Gomes Lessa Altieri ${ }^{1}$, Letícia Pacolla Izique ${ }^{1}$, Carolina Isper ${ }^{1}$, Gilberto Mendes Menderico JR ${ }^{2}$}

\begin{abstract}
Nassar ACF, Garcia DO, Salvio JRC, Altieri NGFL, Izique LP, Isper C, Menderico Jr GM. HPV infection as a risk factor of esophagus squamous cell carcinoma and it prognosis / A infecção do HPV como fator de risco para o Carcinoma de células escamosas de esôfago e seu prognóstico. Rev Med (São Paulo). 2021 March-April;100(2):144-51.

ABSTRACT: Esophageal cancer is the 8th most common cancer in the world, with a survival rate of around $20 \%$ in five years. The most common histological type is squamous cell carcinoma, which presents geographical and ethnic variations. The risk factors for this pathology are not well defined. One of the main ones is infection by the Human Papilloma Virus (HPV), which presents frequent but transient conditions, which may regress spontaneously. The subtypes with the highest risk of malignancy are 16 and 18. Thus, a systematic review of the literature was performed based on the reference data, such as Medline, The Cochrane Library, Embase and Lilacs. Articles in languages other than English, Portuguese and Spanish; articles where the full recovery was not possible; those that had missing or insufficient data for evaluation the variables under study; those that focused on the pediatric population, animals and/or cell lines; presence of HPV in extraesophageal locations; benign lesions or malignant neoplasms other than squamous cell carcinoma (SCC); and case reports or case series were excluded. The study analyzed 64 abstracts of articles, 25 of which were included in this review and 39 excluded. The study demonstrated the presence of HPV in the esophageal SCC in $648(24.4 \%)$ of the 2647 neoplastic tissue samples, detected by different techniques. We observed, however, that this great prevalence is very related to the geographic region studied. Finally, it

RESUMO: $O$ câncer de esôfago é o $8^{\circ}$ mais comum no mundo, com uma taxa de sobrevida em torno de $20 \%$ em cinco anos. O tipo histológico mais frequente é o carcinoma de células escamosas, o qual apresenta variações geográficas e étnicas. Os fatores de riscos para tal patologia não são bem definidos. Um dos principais é a infecção pelo Papiloma Vírus Humano (HPV), que apresenta quadros frequentes, porém transitórios, podendo regredir espontaneamente. Os subtipos que apresentam maior risco de malignidade são o 16 e 18. Dessa forma, uma revisão sistemática da literatura foi realizada a partir da base de dados de referência, como Medline, The Cochrane Library, Embase, Lilacs. Foram aplicados os critérios de exclusão e inclusão e assim obteve o resultado e assim 25 artigos incluídos nessa revisão e 39 excluídos. O estudo demonstrou presença do HPV no CEC de esôfago em 648 (24,4\%) das 2647 amostras de tecidos neoplásicos, detectados através de diferentes técnicas. O que foi observado, todavia, é que essa grande prevalência muito se relaciona à região geográfica estudada. Por fim, foi considerado que de fato existe uma relação entre o HPV e o CEC de esôfago, como analisado na grande maioria dos estudos, porém ainda não se pode chegar a uma conclusão efetiva acerca da sua interferência no prognóstico do paciente.
\end{abstract} was considered that in fact there is a relationship between HPV and esophageal SCC, as analyzed in the vast majority of studies, but it is not yet possible to reach an effective conclusion about its interference in the patient's prognosis.

Descritores: Infecção por HPV; Infecção por Papilomavírus Humano; Câncer de esôfago; Neoplasia de esôfago; Prognóstico.

Keywords: HPV infections; Human Papillomavirus infection; Esophagus cancer; Esophageal neoplasm; Prognostic

Institution: Centro Universitário Lusíada

1. Acadêmica do Centro Universitário Lusíada, Santos, SP. ORCID: Nassar ACF - 0000-0002-8109-1885; Garcia DO - 0000-0001-8257-2325; Salvio JRC - 0000-0001-8470-2920; Altieri NGGL - 0000-0003-4888-3204; Izique LP - 0000-0003-1894-9129; Isper C - 0000-0002-1372-0387. Email: ana. ferrari.nassar@gmail.com, garciadebora17@gmail.com,juliaroyd@hotmail.com, iziqueleticia@gmail.com,

2. Professor da Disciplina de Clínica Cirúrgica do Curso de Medicina do Centro Universitário Lusíada, Santos, SP. ORCID: 000-0001-7281-4044. gmmenderico@gmail.com.

Correspondence: Nathalie Gabrielle Gomes Lessa Altieri. Rua Bolívar 74, apto 74 - Boqueirão. Santos, SP. Email: nathalie gabi.g@hotmail.com. 


\section{INTRODUCTION}

Q sophageal cancer is the eighth most common cancer-related death ${ }^{1}$. In Brazil, excluding non-melanoma skin cancer, it is the sixth most incident among men and thirteenth among women ${ }^{2}$. Its prognosis is poor, with a survival rate of around $20 \%$ over five years. The most common histological type in the world is still squamous cell carcinoma, with geographical and ethnic variations, followed by adenocarcinoma ${ }^{1}$. The risk factors for the development of esophageal squamous cell carcinoma are not well defined, with the use of alcohol and tobacco accountable as the main etiological factors. Infection with the human papilloma virus (HPV) has been reported as a risk factor for this neoplasm ${ }^{1}$. HPVs are viruses capable of infecting the skin or mucous membranes. The infection is very frequent but transient, spontaneously regressing most of the time. In the minority of cases, the infection may persist and develop precursor lesions which, if not identified and treated, can progress to cancer, especially in the cervix, but also in the vagina, vulva, anus, penis, oropharynx and mouth, and the subtypes 16 and 18 are responsible for $80 \%$ of the cases of malignancy ${ }^{1}$.

\section{OBJETIVE}

The aim of the study is to perform a systematic review of the literature in order to establish the correlation between esophageal squamous cell carcinoma and HPV infection, as its risk factor and to evaluate its prognosis in relation to lesions not linked to the virus.

\section{MATERIALS AND METHODS}

\section{Ethical aspects}

The present study was not submitted to the Ethics Council of the Institution involved because it is a systematic review, presenting only articles already published.

\section{Search strategy, inclusion and exclusion criteria}

Three authors searched the following electronic database: Medline, The Cochrane Library, Embase and Lilacs (Latin American and Caribbean Health Sciences). The search involved articles in Portuguese, English and Spanish, published until 2018, with a broad search strategy to avoid publication bias. The following keywords were used: "squamous-cell carcinoma", "esophagus cancer", "human papillomavirus", "HPV", "squamous cell carcinoma” and "esophageal cancer".

Articles in languages other than those mentioned above were excluded, or those that concluded that full recovery was not possible. Those studies that did not contain data or insufficient data to evaluate the variables under study were also excluded. Articles that focused on the pediatric population, animals, cell lines, the presence of HPV in extra-esophageal locations, benign lesions or malignant neoplasms other than squamous cell carcinoma (SCC), case reports or case series were also excluded. Systematic review articles were used to discuss the results, not being used as part of these.

\section{Data extraction}

The data were extracted by two independent authors. For this, a data registration form was used for this purpose, including: type of study, country of origin, time of sample collection, number of patients with esophageal SCC, numbers of patients in the control groups, harmful habits (smoking and drinking), technology used in the study for the detection of HPV (polymerase chain reaction - PCR, in situ hybridization and/or immunohistochemistry - IHC), number of patients affected by HPV, identification of HPV type (HPV16 and/or HPV18) and 5-year survival.

\section{Data analysis}

Initially, to facilitate the analysis, the articles were organized in the following groups: (1) oral or oropharyngeal HPV infection in patients with esophageal SCC; (2) Esophageal SCC and correlation with HPV; (3) Harmful habits and patients with esophageal SCC/HPV positive; (4) Overall 5-year survival of positive and negative HPV esophageal SCC patients.

We used the Microsoft Excel software (Microsoft Corp. (r), Redmond, WA) to tabulation of data and calculations of the weighted average, frequency and 95\% confidence interval $(95 \% \mathrm{CI})$. The SPSS (r) version 17.0 (SPSS (r) Inc.; Illinois, USA) software for regressions was used to assess the risk of HPV infection in each group, with calculation of odds ratios (OR) and $95 \%$ CIs. In all of these analyzes, the likelihood of occurrence of a $\alpha$ or type I error was considered to be less than $5 \%(p<0.05)$.

\section{RESULTS}

The study analyzed 64 abstracts of articles, excluding articles approaching only about HPV molecular biology; unrelated to the subject (28); benign neoplasms or only the HPV infection in the esophagus (15); studies that did not specify the type of malignant neoplasm or those including malignant neoplasms from other HPVassociated topographies; making it impossible to calculate the variables in question (12) and systematic reviews (13); as shown in the flowchart in Figure 1.

Based on these criteria, 25 articles were included in the review, with results obtained according to Tables 1, 2, 3, and 4 and in Figures 2 and 3. 


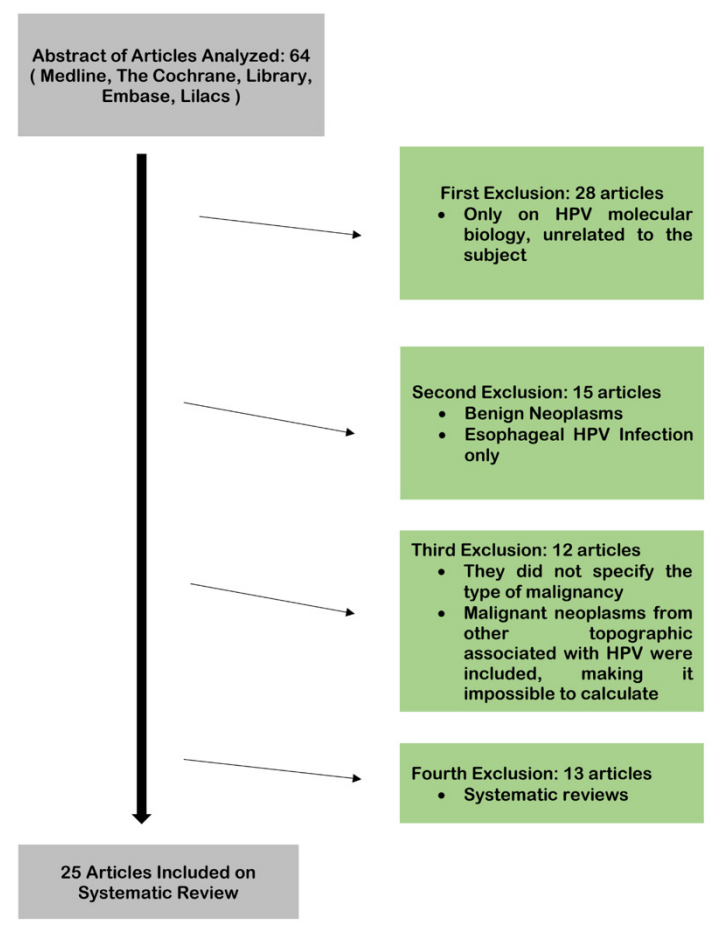

Figure 1: Flowchart of articles

Table 1. Demographic data of patients and sample of studies included in the review

\begin{tabular}{|c|c|c|c|c|c|}
\hline Article & Country & Average age & Men / Womens & Smoking (n/HPV+) & Alcohol (n/HPV+) \\
\hline Cao $2014^{4}$ & China & $60(42-78)$ & $84 / 21$ & $63 / 14$ & $52 / 15$ \\
\hline Dreilich $2006^{5}$ & Suécia & $>65$ & $71 / 29$ & $67 / 10$ & $50 / 6$ \\
\hline Fuhirata $1993^{6}$ & Japão & $60-70$ & $62 / 9$ & $\varnothing$ & $\varnothing$ \\
\hline Kumar $2015^{7}$ & Índia & $>45$ & $67 / 34$ & $53 / 11$ & \\
\hline Souto-Damin $2016^{8}$ & Brasil & $58,4(45-85)$ & $105 / 50$ & $\varnothing$ & $\varnothing$ \\
\hline Wang $2015^{9}$ & China & $49,9(40-66)$ & $147 / 3$ & $144 / 27$ & $147 / 26$ \\
\hline Mehyar $2015^{10}$ & China & ø & $\varnothing$ & $\varnothing$ & ø \\
\hline Turkay $2016^{11}$ & Turquia & $>70$ & $18 / 15$ & $\varnothing$ & $\varnothing$ \\
\hline Soheli F $2016^{12}$ & Irã & 62,63 & $70 / 33$ & $\varnothing$ & $\varnothing$ \\
\hline Prokash $2017^{13}$ & Índia & $60(42-70)$ & $9 / 9$ & $10 / 5$ & $5 / 2$ \\
\hline Costa $2017^{14}$ & Brasil & $60,9(41-92)$ & $100 / 23$ & $99 / 10$ & $97 / 10$ \\
\hline Bahrnassy $2005^{15}$ & Egito & $61,3(40-72)$ & $34 / 16$ & $\varnothing$ & $\varnothing$ \\
\hline Zhang $2017^{16}$ & China & $62(44-76)$ & $155 / 37$ & $62 / 40$ & $59 / 38$ \\
\hline Geßner $2010^{17}$ & Malawi & 60 & $27 / 13$ & $\varnothing$ & $\varnothing$ \\
\hline Haeri $2013^{18}$ & Irã & $59,6(30-83)$ & $16 / 14$ & $\varnothing$ & $\varnothing$ \\
\hline Fahradi $2005^{19}$ & Irã & $54(25-75)$ & $38 / 38$ & $\varnothing$ & $\varnothing$ \\
\hline Antonsson $2010^{20}$ & Austrália & 65,2 & $140 / 127$ & $188 / 75$ & $94 / 41$ \\
\hline Guo $2012^{21}$ & China & $51-60$ & $712 / 488$ & $519 / \varnothing$ & 203/ø \\
\hline Benamouzig $1992^{22}$ & França & $\varnothing$ & $\varnothing$ & $\varnothing$ & $\varnothing$ \\
\hline Talamini $2000^{23}$ & Itália & $>57$ & $41 / 4$ & $36 / 29$ & $41 / 29$ \\
\hline Haohua $2014^{24}$ & China & 63 & $144 / 33$ & $\varnothing$ & $\varnothing$ \\
\hline Hayedeh $2013^{25}$ & Irã & $62(41-82)$ & $14 / 16$ & $\varnothing$ & $\varnothing$ \\
\hline Herbster $2012^{26}$ & Brasil & 60,31 & $184 / 52$ & $211 / 24$ & $199 / 18$ \\
\hline Andrzej $2012^{27}$ & Polônia & 59 & $49 / 7$ & $\varnothing$ & $\varnothing$ \\
\hline Herrera-Goepfert $2009^{28}$ & México & $61(27-85)$ & $47 / 13$ & $28 / 6$ & $36 / 9$ \\
\hline
\end{tabular}


Table 2. Prevalence of HPV in esophageal squamous of cells carcinoma samples from studies included in the review

\begin{tabular}{|c|c|c|c|}
\hline Article & Study time (Years) & $\mathbf{N}($ CEC $)$ & HPV positive cases / (\%) \\
\hline Cao $2014^{4}$ & 02 & 105 & $29(27,6)$ \\
\hline Dreilichi $2006^{5}$ & 10 & 100 & $16(16)$ \\
\hline Fuhirata $1993^{6}$ & 11 & 71 & $24(33,8)$ \\
\hline Kumar $2015^{7}$ & 04 & 101 & $22(22)$ \\
\hline Souto-Damin $2006^{8}$ & 07 & 165 & $26(15,7)$ \\
\hline Wang $2015^{9}$ & 03 & 150 & $27(18)$ \\
\hline Mehyar $2015^{10}$ & 02 & 198 & $158(79,7)$ \\
\hline Turkay $2016^{11}$ & 13 & 33 & $3(9,09)$ \\
\hline Soheili F $2016^{12}$ & 06 & 103 & $11(10,7)$ \\
\hline Prakash $2017^{13}$ & 01 & 18 & $09(50)$ \\
\hline Costa $2017^{14}$ & 01 & 87 & $12(13,8)$ \\
\hline Bahrnassy $2005^{15}$ & 02 & 50 & $27(54)$ \\
\hline Zhang $2017^{16}$ & 03 & 192 & $67(34,9)$ \\
\hline Geßner $2010^{17}$ & / & 40 & $6(15)$ \\
\hline Haeri $2013^{18}$ & 02 & 130 & $0(0)$ \\
\hline Fahradi $2005^{19}$ & 05 & 38 & $14(36,8)$ \\
\hline Antonsson $2010^{20}$ & 03 & 222 & $8(3,5)$ \\
\hline Guo $2012^{21}$ & 01 & 300 & $99(33)$ \\
\hline Benamouzig $1992^{22}$ & l & 12 & $5(41,6)$ \\
\hline Talamini $2000^{23}$ & 08 & 45 & $2(4,4)$ \\
\hline Haohua $2014^{24}$ & 12 & 177 & $6(3,3)$ \\
\hline Hayedeh $2013^{25}$ & 02 & 30 & $0(0)$ \\
\hline Herbster $2012^{26}$ & 09 & 264 & $34(13)$ \\
\hline Andrzej $2012^{27}$ & 03 & 56 & $28(50)$ \\
\hline Herrera-Goepfert $2009^{28}$ & 08 & 60 & $15(25)$ \\
\hline Total & & 2647 & $648(24,4 ;$ IC95 16,6 - 32,3) \\
\hline
\end{tabular}

Table 3. 5-year survival of patients with esophageal SCC according to studies included in the review.

\begin{tabular}{ll}
\hline Article & 5 year survival (HPV +/- \%) \\
\hline Cao $2014^{4}$ & $65,5 / 43,4$ \\
Dreilich $2006^{5}$ & $11,0 / 11,0$ \\
Fuhirata $1993^{6}$ & $9,2 / 22,8$ \\
Kumar 2015 & $72,2 / 49,3$ \\
Antonsson 2010 20 & $75 / 36$ \\
Herbster 2012 26 & $0 / 0$ \\
Wang 2015 & $48 / 21$ \\
5 years survival & HPV+ 35,9\% (IC95: 19,9 - 51,9) \\
& HPV- 21,9\% (IC95: 8,7 - 35,1) \\
\hline
\end{tabular}

Table 4. HPV as a risk factor of esophageal SCC in the studies included in the review

\begin{tabular}{|c|c|c|c|c|}
\hline Article & HPV + & HPV & SCC & Control \\
\hline Ge $\beta$ ner $2010^{17}$ & 7 & 47 & 40 & 15 \\
\hline Haeri $2013^{18}$ & 0 & 0 & 30 & 30 \\
\hline Fahradi $2005^{19}$ & 19 & 59 & 40 & 38 \\
\hline Antonsson $2010^{20}$ & 8 & 269 & 222 & 55 \\
\hline Guo $2012^{21}$ & 154 & 1046 & 300 & 900 \\
\hline Benamouzig $1992^{22}$ & 6 & 17 & 15 & 8 \\
\hline Andrzej $2012^{23}$ & 32 & 59 & 56 & 35 \\
\hline Total $(\mathrm{p} \leq 0,05)$ & 226 & 1558 & 702 & 1081 \\
\hline
\end{tabular}




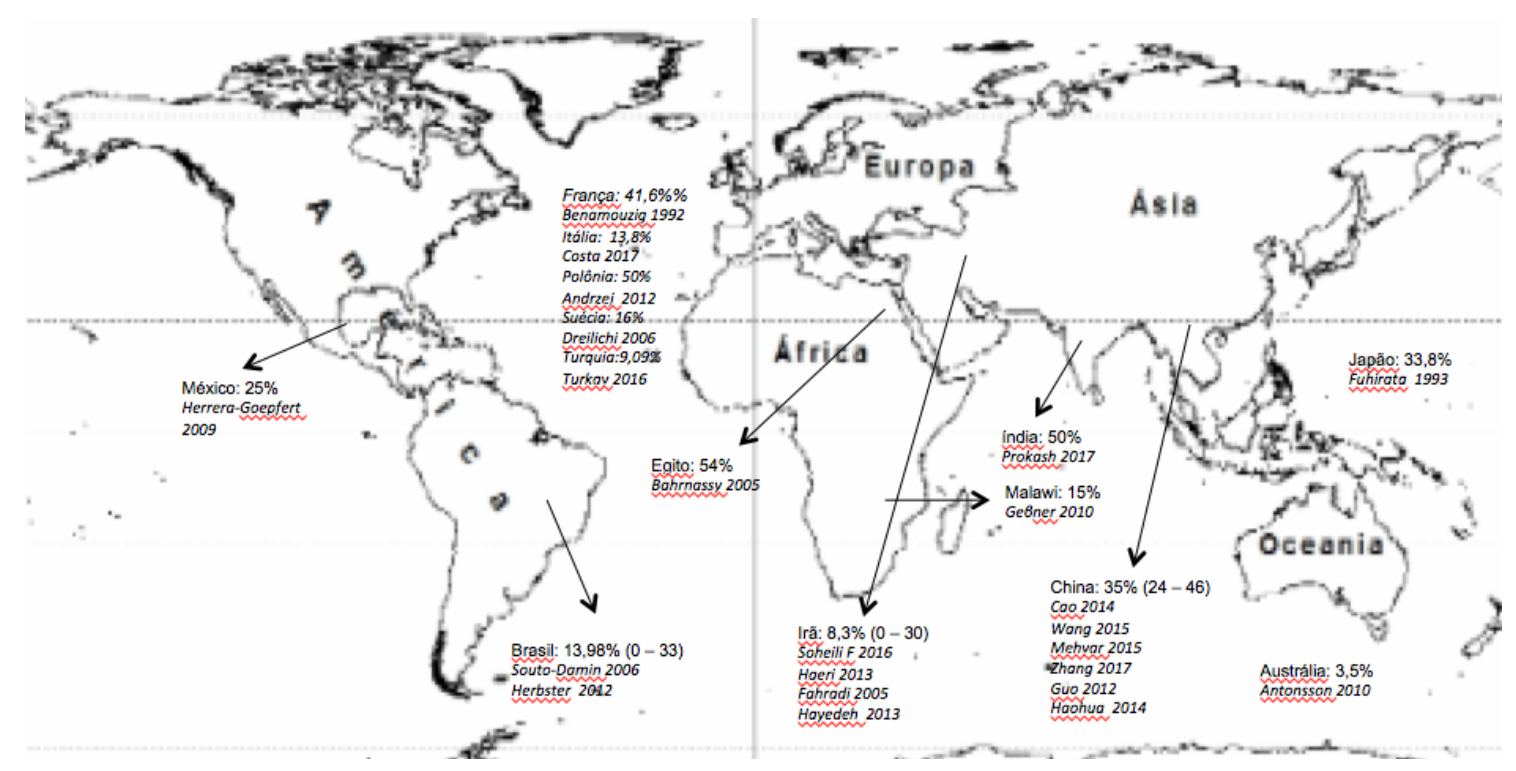

Figure 2. Articles according to the countries of publication.

\section{DISCUSSION}

Esophageal carcinoma can already appear as a frankly malignant lesion or appear as a progression of premalignant lesions. The tumor begins in the internal lining
Figure 3. Forest-plot OR.

layer of the organ (mucosa), penetrating the submucosa, muscular layer and adventitia, and may infiltrate adjacent organs, such as the trachea or the aorta.

Its etiology is associated with the histological type of the disease, and the squamous cell carcinoma is still 
the most common and strongly related to smoking and alcohol consumption, and adenocarcinoma, associated with Barrett's esophagus and obesity. Among other factors described, consumption of food and water rich in nitrates and nitrosamines, low intake of fruits and vegetables, mycotoxins, consumption of high temperature drinks, palmoplantar tylosis, Plummer-Vinson syndrome, achalasia, caustic strictures and genetic factors are also related to this type of cancer.

HPV has been implicated as a risk factor for esophageal squamous cell carcinoma since 1982 , by the study by Syrjaren et al. ${ }^{29}$, describing the progression of the lesion from flat condyloma to invasive carcinoma. Among the 100 types of HPV, the 16 and 18 are those with the highest rates of oncogenic predisposition. They are attracted to squamous epithelial cells on wet surfaces, including the mucosa of the genital and aerodigestive tracts, in addition to the skin, and can remain throughout their life cycle, including replication ${ }^{28}$.

The study by Patham et al. ${ }^{30}$ in 2017 analyzed the presence of esophageal papilloma and HPV through PCR in patients undergoing upper digestive endoscopy in 13 years, with 60 cases of papilloma found in this period, and of these, 19 paraffinized tissues remaining from incisional biopsy of the lesion performed in the procedure underwent DNA virus research 9 had positive PCR for HPV 16. $(47.4 \%)^{27}$.

Our study showed the presence of HPV in the esophageal SCC in 648 (24.4\%) of the 2647 samples (Table 2) of neoplastic tissues, detected using different techniques. This prevalence varies widely according to location, with higher incidences presented in Chinese studies, in which the prevalence of the virus in cases of esophageal SCC was around 35\%. The meta-analysis by Ludmir et al. ${ }^{31}$, showed the same geographical difference, especially when the patients involved were from Asia, in which the percentage of HPV in the esophageal SCC reached $38 \%$, in contrast to studies involving patients from South America, in which the study with the highest prevalence was $16.6 \%{ }^{21}$. The systematic review performed by Zhang et al..$^{32}$ in 2014 , analyzed 26 studies with a total of 3026 patients with esophageal SCC from all regions of China, assessing the presence of HPV 16 in neoplastic tissues. A prevalence of $39.7 \%$ was demonstrated, with a greater predominance in the southern region of the country, which had a prevalence of $47.8 \%$, despite presenting the lowest number of cases studied than in other regions ${ }^{21}$.

The 2015 meta-analysis by Guo et al. ${ }^{33}$, also performed in China, researched the presence HPV 18 in patients with esophageal SCC, involving 2556 patients, showing that this subtype was present in $4.1 \%$ of the lesions ${ }^{33}$.

In contrast, the 2013 systematic review by $\mathrm{Li}$ et al. ${ }^{34}$, analyzed the remaining histological analysis of 8990 cases of esophageal SCC, which underwent PCR, with prevalence of $22.2 \%$ of virus DNA, with a predominance of HPV $16^{34}$. The importance of high prevalence of HPV infection in China is found in the country's large population, associated with the flow of emigration and transit of its citizens around the world after its economic expansion.

The articles evaluated in our study suggest a strong association between HPV and esophageal malignancy in question, in view of the prevalence of the virus in the studies and the OR calculated from 7 present case-control articles was 3.93 (CI: 95, 3.83-4.02). It must be remembered that, as shown in table 1, patients infected with HPV also have a history of smoking and drinking habits, which can be a confusing factor for establishes it as a risk factor. The systematic review by $\mathrm{Li}$ et al ${ }^{34}$ had as a result of its OR 3.32 (CI: 95, 2.26-4.87) in 17 evaluated articles. ${ }^{34}$ The 2013 Syrjänen $^{29}$ meta-analysis, involving 39 studies to verify the difference between the virus detection methods, demonstrated that the presence of the virus cannot really be associated with the etiology of lesion ${ }^{29}$.

The meta-analysis by Guo et al. ${ }^{35}, 2016$, involved 1184 cases of esophageal SCC, analyzing the risk of death in positive and negative HPV patients, demonstrating that the presence of the virus $(0.73$ relative risk, CI:95, 0.441.21) has no interference in the prognosis of the neoplasia ${ }^{35}$. The articles in which the overall 5-year survival analysis (Table 3) was present, there was no difference between patients infected by the virus and those not infected.

\section{CONCLUSION}

The studies evaluated by systematic review and meta-analysis show that there is an association between HPV and esophageal cancer, especially in certain geographic areas, without having greater influences on the patient's prognosis. More studies, essentially prospective cohort studies should be performed to detail its role in the oncogenesis of esophageal SCC and thus, establish it definitively as a risk factor and thus, build prevention strategies.

Authors' participation: Gilberto Mendes Menderico Júnior: Prof. Dr. project advisor and supervisor. Nathalie Gabrielle Gomes Lessa
Altieri: Academic of medical school, that participated in the planning, design, critical intellectual review, data analysis and preparation
of the manuscript until final approval for publication. Leticia Pacolla Izique: Academic of medical school, that participated in the plan-
ning, design, critical intellectual review, data analysis and preparation of the manuscript until final approval for publication Ana Carolina
Ferrari Nassar: Academic of medical school, that participated in the planning, design, critical intellectual review, data analysis and
preparation of the manuscript until final approval for publication. Júlia Royd Costa Salvio: Academic of medical school, that participated
in the planning, design, critical intellectual review, data analysis and preparation of the manuscript until final approval for publication.
Débora de Oliveira Garcia: Academic of medical school, that participated in the planning, design, critical intellectual review, data analysis
and preparation of the manuscript until final approval for publication. Carolina Isper: Academic of medical school, that participated
in the planning, design, critical intellectual review, data analysis and preparation of the manuscript until final approval for publication. 


\section{REFERENCES}

1. Tiftikçi A, Kutsal E, Altıok E, et al. Analyzing esophageal squamous cell papillomas for the presence of human papilloma virus. Turk J Gastroenterol. 2017;28:176-8. doi: 10.5152/tjg.2017.16636.

2. Instituto Nacional de Câncer. Câncer de esôfago [atualização 22 out. 2018]. Disponível em: https://www.inca.gov. br/tipos-de-cancer/cancer-de-esofago.

3. Tustumi F, Kimura CMS, Takeda RH, et al. Fatores prognósticos e análise de sobrevida no carcinoma esofágico. ABCD Arq Bras Cir Dig. 2016;29(3):138-41. doi: 10.1590/01026720201600030003.

4. Cao F, Han H, Zhang F, Wang B, et al. HPV infection in esophageal squamous cell carcinoma and its relationship to the prognosis of patients in northern China. Scientific World J. 2014;2014:804738. doi: 10.1155/2014/804738.

5. Dreilich M, Bergqvist M, Moberg M, Brattström D, Gustavsson I, et al. High-risk human papilloma virus (HPV) and survival in patients with esophageal carcinoma: a pilot study. BMC Cancer 2006, 6:94. doi: 10.1186/14712407-6-94.

6. Furihata M, Ohtsuki Y, Ogoshi S, et al. Prognostic significance of human papillomavirus genomes (type-16, -18) and aberrant expression of p53 protein in human esophageal cancer. IJC 1993, 2910540211. doi: 10.1002/ ijc. 2910540211.

7. Kumar R1, Ghosh SK, Verma AK, et al. p16 expression as a surrogate marker for HPV infection in esophageal squamous cell carcinoma can predict response to neo-adjuvant chemotherapy. Asian Pac J Cancer Prev. 2015;16(16):7161-5. doi: 10.7314/apjcp.2015.16.16.7161.

8. Souto Damin AP, Guedes Frazzon AP, de Carvalho Damin D, et al. Detection of human papillomavirus DNA in squamous cell carcinoma of the esophagus by auto-nested PCR. Dis Esophagus. 2006;19(2):64-8. doi: 10.1111/j.1442$-2050.2006 .00541 . x$.

9. Wang WL, Wang YC, Lee CT, et al. The impact of human papillomavirus infection on the survival and treatment response of patients with esophageal cancers. J Dig Dis. 2015;16(5):256-63. doi: 10.1111/1751-2980.12236.

10. Mehryar M, Li SY, et al. Prevalence of human papillomavirus in esophageal carcinoma in Tangshan, China. World J Gastroenterol. 2015;21(10):2905-2911. doi: 10.3748/wjg. v21.i10.2905.

11. Türkay DÖ, Vural Ç, et al. Detection of human papillomavirus in esophageal and gastroesophageal junction tumors: A retrospective study by real-time polymerase chain reaction in an instutional experience from Turkey and review of literature. Pathol Res Pract. 2016;212(2):77-82. doi: 10.1016/j.prp.2015.10.007.

12. Soheili F, Heidary N, Rahbar M, et al. Human papillomavirus and its clinical relevance in oesophageal squamous cell carcinoma in a Kurdish population in the west of Iran. Infect Dis (Lond). 2016 Apr;48(4):270-273. doi:
10.3109/23744235.2015.1109134.

13. Prakash Saxena P U, Fernandes DJ, Vidyasagar MS, Singh A, Sharan K. Detection of human papilloma virus in patients with squamous cell carcinoma of the esophagus planned for definitive chemo-radiotherapy, and a study of their clinical characteristics. J Can Res Ther 2016;12:871-5. doi: 10.4103/0973-1482.168971.

14. Costa AM, Tavares Guerreiro Fregnani JH, et al. HPV infection and p53 and p16 expression in esophageal cancer: are they prognostic factors? Infect Agents Cancer. 2017;12:54. doi: 10.1186/s13027-017-0163-4.

15. Bahnassy AA, Zekri AR, Abdallah S, El-Shehaby AM, Sherif GM. Human papillomavirus infection in Egyptian esophageal carcinoma: correlation with p53, p21, mdm2, C-erbB2 and impact on survival. Pathol Int. 2005;55(2):5362. doi: $10.1111 / \mathrm{j} .1440-1827.2005 .01804 . x$.

16. Zhang D, Zhang W, Liu E, et al. Human papillomavirus infection increases the chemoradiation response of esophageal squamous cell carcinoma based on P53 mutation. Radiother Oncol. 2017;124(1):155-60. doi: 0.1016/j. radonc.2017.06.008.

17. GeßnerAL, Borkowetz A, Baier M, et al. Detection of HPV16 in Esophageal Cancer in a High-Incidence Region of Malawi. Int J Mol Sci. 2010;19(2):557. doi: 10.3390/ ijms 19020557.

18. Haeri H, Mardani O, Asadi-Amoli F, et al. Human papilloma virus and esophageal squamous cell carcinoma. Acta Med Iran. 2014;52(3):197-200.

19. Farhadi M, Tahmasebi Z, Merat S, et al. Human papillomavirus in squamous cell carcinoma of esophagus in a highrisk population. World J Gastroenterol. 2005;11(8):1200-3. doi: 10.3748/wjg.v11.i8.1200.

20. Antonsson A, Nancarrow DJ, Brown IS, et al. High-risk human papillomavirus in esophageal squamous cell carcinoma. Cancer Epidemiol Biomarkers Prev. 2010; 19(8):2080-7. doi: 10.1158/1055-9965.EPI-10-0033.

21. Guo F, Liu Y, Wang X, et al. Human papillomavirus infection and esophageal squamous cell carcinoma: a case-control study. Cancer Epidemiol Biomarkers Prev. 2012;21(5):780-5. doi: 10.1158/1055-9965.EPI-11-1206.

22. Benamouzig R, Pigot F, Quiroga G, et al. Human papillomavirus infection in esophageal squamous-cell carcinoma in western countries. Int J Cancer. 1992;50(4):549-52. doi: 10.1002/ijc.2910500409.

23. Talamini G, Capelli P, Zamboni G, et al. Alcohol, smoking and papillomavirus infection as risk factors for esophageal squamous-cell papilloma and esophageal squamous-cell carcinoma in Italy. Int J Cancer. 2000;86(6):874-8. doi: 10.1002/ijc.2910500409.

24. Haohua Teng, Xiaojing Li, Xiuping Liu, et al. The absence of human papillomavirus in esophageal squamous cell carcinoma in East China Int J Clin Exp Pathol. 2014;7(7):4184-93.

25. Hayedeh Haeri, Mardani O, Asadi-Amoli F, et al. Human 
papilloma virus and esophageal squamous cell carcinoma. Acta Med Iran. 2014;52(3):197-200.

26. Herbster S, Ferraro CT, Koff NK, et al. HPV infection in Brazilian patients with esophageal squamous cell carcinoma: interpopulational differences, lack of correlation with surrogate markers and clinicopathological parameters. Cancer Lett. 2012; 29; 326(1):52-8. doi: 10.1016/j. canlet.2012.07.018.

27. Dąbrowski A., Kwaśniewski W., Skoczylas T, et al. Incidence of human papilloma virus in esophageal squamous cell carcinoma in patients from the Lublin region. World J Gastroenterol. 2012;18(40):5739-44. doi: 10.3748/wjg. v18.i40.5739.

28. Herrera-Goepfert R, Lizano M, Akiba S, et al. Human papilloma virus and esophageal carcinoma in a Latin-American region. World J Gastroenterol. 2009;15(25):3142-7. doi: 10.3748/wjg.15.3142.

29. Syrjänen K, Pyrhönen S, Aukee S, et al. Squamous cell papilloma of the esophagus: a tumour probably caused by human papilloma virus (HPV). Diagn Histopathol. 1982;5:291-6.

30. Pantham G, Ganesan S, Einstadter D. Assessment of the incidence of squamous cell papilloma of the esophagus and the presence of high-risk human papilloma virus. Dis Esophagus. 2017;1;30(1):1-5. doi: 10.1111/dote.12475.
31. Ludmir EB, Stephens SJ, Palta M, et al. Human papillomavirus tumor infection in esophageal squamous cell carcinoma. J Gastrointest Oncol. 2015;6(3):287-95. doi: 10.3978/j.issn.2078-6891.2015.001.

32. Zhang SK, Guo Lw, Chen Q, et al. Prevalence of human papillomavirus 16 in esophageal cancer among the Chinese population: a systematic review and meta-analysis. Asian Pacific Journal of Cancer Prevention. APJCP. 2014;15(23):101439. doi: 10.7314/apjcp.2014.15.23.10143.

33. Guo LW, Zhang SK, Liu SZ, et al. Human papillomavirus type-18 prevalence in oesophageal cancer in the Chinese population: a meta-analysis. Epidemiol Infect. 2016;144(3):469-77. doi: 10.1017/S0950268815001703.

34. Li X, Gao C, Yang Yet al. Systematic review with metaanalysis: the association between human papillomavirus infection and esophageal cancer. Aliment Pharmacol Ther. 2014;39(3):270-81. doi: 10.1111/apt.12574.

35. Guo L, Liu S, Zhang S, et al. Human papillomavirus-related esophageal cancer survival: a systematic review and metaanalysis. Medicine (Baltimore). 2016; 95(46):e5318. doi: 10.1097/MD.0000000000005318.

Received: 2020, July 11

Accepted: 2021, March 09 